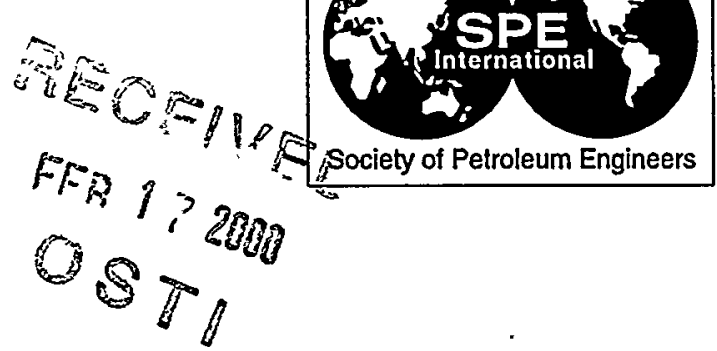

\title{
Development and Testing of Insulated Drillpipe
}

J. T. Finger, SPE, and R. D. Jacobson, Sandia National Laboratories, and A. T. Champness, SPE, Drill-Cool Systems, Inc.

\section{Copyright 2000, IADCISPE Drilling Conference}

This paper was prepared for presentation at the 2000 IADC/SPE Drilling Conference held in New Orleans, Louislana, 23-25 February 2000.

This paper was selected for presentation by an IADC/SPE Program Committee following review of Infomation contained in an abstract submitted by the author(s). Contents of the paper, as presented, have not been reviewed by the International Association of Driting Contractors or the Society of Petroleum Engineers and are subject to correction by the author(s). The matertal, as presented, does not necessarily reflect any position of the IADC or SPE thei Tho materlal, as presen Pap, does not necess officers, or members. Papers presented at the IADCJSPE meetings are subject to publication reviow by Editorial Committees of the IADC and SPE. Electronic reproduction, distribution, or storage of any part of this paper for commercial purposes without the written consent of the Society of Petroleum Engineers is prohibited. Permission to reproduce in print is restricted to an abstract of not more than 300 words; illustrations may not be copied. The abstract must contain consplcuous acknowledgment of where and by whom the paper was presented. Write Llbrarian, SPE, P.O. Box 833836, Richardson, TX 75083-3836, U.S.A., fax 01-972-952-9435.

\section{Abstract}

The Geothermal Research Department at Sandia National Laboratories, in collaboration with Drill Cool Systems, Inc., has worked to develop and test insulated drillpipe (IDP). IDP will allow much cooler drilling fluid to reach the bottom of the hole, making possible the use of downhole motors, electronics, and steering tools that are now unusable in high-temperature formations. Other advantages of cooler fluid include reduced degradation of drilling fluid, longer bit life, and reduced corrosion rates.

The paper describes the theoretical background, laboratory testing, and field testing of IDP. Structural and thermal laboratory testing procedures and results are described. Results are given for a field test in a geothermal well, in which circulating temperatures in IDP are compared with those in conventional drillpipe (CDP) at different flow rates. A brief description of the software used to model wellbore temperature and to calculate sensitivity to IDP design differences is included, along with a comparison of calculated and measured wellbore temperatures in the field test. Analysis of mixed (IDP and CDP) drill strings and discussion of where IDP should be placed in a mixed string are presented.

\section{Introduction}

This project was directed at a fundamental problem - the dámaging effect of high formation temperature on drilling tools, materials, and processes. When drilling fluid gets too hot, it can irreversibly deteriorate in its ability to carry the drilled cuttings, can increase drillpipe corrosion by orders of magnitude, can shorten the life of bits and other downhole tools, can prevent the use of downhole motors and electronic instrumentation/tools, and can even affect borehole stability and well control. Each of these problems can be attacked by individual technology developments, but all of them can be solved or greatly mitigated by simply cooling the downhole environment with lower-temperature drilling fluid. IDP delivers drilling fluid to the bottom of the hole at a much lower temperature than conventional drillpipe (CDP).

More detailed calculations and measurements are presented later, but an example of DP's effect in a geothermal well is shown in Fig. 1. In this and other fluid-temperature plots, the right-hand side of the curve shows temperature in the annulus and the left-hand side shows temperature in the drillpipe. Several important points are illustrated by this calculation: 1) Bottomhole fluid temperature is reduced from $401^{\circ} \mathrm{F}$ with $\mathrm{CDP}$ to $166^{\circ} \mathrm{F}$ with $\mathrm{IDP}$ - this is the temperature that steering tools, mud motors, and other electronics must survive. 2) Maximum fluid temperature (which is not at the bottom of the hole) is reduced from $406^{\circ} \mathrm{F}$ to $214^{\circ} \mathrm{F}$ - this is the maximum temperature seen by drilling fluid additives. 3 ) Returns temperature is higher with IDP, $196^{\circ} \mathrm{F}$ versus $163^{\circ} \mathrm{F}-$ this may mean that mud coolers are necessary, but it also means that more heat is being removed from the hole, which will be beneficial for logging and cementing after drilling.

\section{IDP Construction}

The insulated drillpipe described in this paper was constructed by welding a liner tube inside conventional drillpipe (Fig. 2) and filling the annulus between the tubulars with an insulating material. By using the compressive strength of the insulation to support the liner tube against intemal pressure, the liner tube can be made of a thinner material, saving cost and weight, and preserving the inside diameter as large as possible.

Two criteria, compressive strength and conductivity, drive the choice of an insulating material. Required compressive strength can be estimated from the diameters of the drillpipe and liner, along with the expected internal pressure, but typical values are less than 8,000 psi.

Conductivity of the insulation does not need to be exceptionally low, because there is an alternate heat-flow path through the uninsulated tool joints. That is, below a nominal value of conductivity, further improvement in the insulation has little effect on the total heat flow because of the heat losses (gains) through the tool joints. Drilling fluid temperatures are calculated for three values $(k=0.05 ; 0.3$, and 1.0 


\section{DISCLAIMER}

This report was prepared as an account of work sponsored by an agency of the United States Government. Neither the United States Government nor any agency thereof, nor any of their employees, make any warranty, express or implied, or assumes any legal liability or responsibility for the accuracy, completeness, or usefulness of any information, apparatus, product, or process disclosed, or represents that its use would not infringe privately owned rights. Reference herein to any specific commercial product, process, or service by trade name, trademark, manufacturer, or otherwise does not necessarily constitute or imply its endorsement, recommendation, or favoring by the United States Government or any agency thereof. The views and opinions of authors expressed herein do not necessarily state or reflect those of the United States Government or any agency thereof. 


\section{DISCLAIMER}

Portions of this document may be illegible in electronic image products. Images are produced from the best available original document. 
$\mathrm{B} / \mathrm{hr}-\mathrm{ft}-\mathrm{F}$ ) of insulation conductivity (Fig. 3) and it can be seen that the variation in insulation properties has little effect relative to the difference between even the poorest insulation and conventional pipe. A number of materials have conductivity in the range or 0.2 to $0.8 \mathrm{~B} / \mathrm{hr}-\mathrm{ft}-\mathrm{F}$, and a selected frac proppant was chosen as the insulation for the IDP.

\section{IDP Structural Considerations}

Because IDP is heavier (approximately $33 \mathrm{lb} / \mathrm{ft}$ ) than CDP (approximately $19.5 \mathrm{lb} / \mathrm{ft}$ ), drill string weight could become a problem in deeper wells; this tensile stress is highest at the top of the drill string. The other controlling stress is the hoop stress in the liner tube caused by mud weight and pump pressure; the liner stress is partially supported by the insulation and is highest at the bottom of the drill string.

If principal stresses in the liner tube are combined and tested by the von Mises criterion, failure conditions can be identified. A plot of combined stress (Fig. 4) for various conditions shows that, in a 20,000-ft well, failure may occur both at top and bottom of a full string of IDP (curve A), if the liner tube does not get full support from the insulation. On the other hand, both a 15,000-ft string of IDP (curve B) and a mixed 20,000-ft string with $10,000 \mathrm{ft}$ of IDP at the top and $10,000 \mathrm{ft}$ of CDP below (curve C) have liner stresses well within the assumed limit of $80,000 \mathrm{psi}$.

Laboratory Structural Test. A prototype joint of IDP was instrumented with strain gages inside and outside and was then pressure-tested to evaluate the support given the liner tube by the insulation. Behavior was generally consistent with calculations, although the internal gages showed that the insulation did not begin picking up significant load until an internal pressure of about $8,000 \mathrm{psi}$.

\section{IDP Thermal Considerations}

Although the conductivity of the insulation material can be known or estimated from the supplier, it is important to know the effective conductivity of the complete drill string. This value is used in modeling the effect of IDP on temperatures in proposed wells or in evaluation of different IDP configurations. A laboratory test of the composite $\mathrm{IDP}$, including the un-insulated joints, showed an effective conductivity that was less than $10 \%$ of conventional drill pipe.

The test procedure was to enclose a section of test pipe in a length of 9-5/8-in casing, with separate supplies of water circulating through the test pipe and through the annulus between the test pipe and the casing (Fig. 5). Test measurements were: cold water temperatures in and out, hot water temperatures in and out, hot and cold water flow rates, and pressure in hot and cold loops.

By measuring the temperature rise through the test pipe and calculating the total heat necessary for that increase, then given the average temperature difference between the two water streams, the conductivity of the pipe wall could be evaluated. (The heat-gain in the pipe was checked by also calculating heat-loss from the annulus; this heat-loss should be slightly greater than the heat-gain in the pipe because the cas- ing, even though insulated on the outside, was also losing heat to the atmosphere.)

The "test pipe" took three different configurations: (1) a straight section of conventional 5-in, $19.5 \mathrm{lb} / \mathrm{ft}$ drillpipe, (2) a straight section of double-walled, insulated pipe with 5-in OD and 3.068-in ID, (3) a section of IDP with an uninsulated NC50 tool joint in the middle. This combination allowed comparison between the insulating value of $\mathrm{DP}$ and $\mathrm{CDP}$, and then evaluation of the effect of introducing an uninsulated section into the drill string.

When conventional drillpipe was replaced with IDP, heat flow through the pipe wall was reduced dramatically. Effective conductivity of the insulation-layered pipe body was 0.41 $\mathrm{B} / \mathrm{hr}-\mathrm{ft}-\mathrm{F}$, compared to the value for steel of approximately 25 .

In an actual IDP drillstring, however, the threaded connections (tool joints) between the individual pipes are not insulated. To evaluate the effect of these joints, an insulated pipe was cut in half, the male and female connections were screwed together, and this assembly was used as the test pipe. With this configuration, the overall effective conductivity of the $\mathrm{DP}$ was $2.35 \mathrm{~B} / \mathrm{hr}-\mathrm{ft}-\mathrm{F}$, which was higher than calculations had suggested. Calculating the effective length of the tool joint showed it to be approximately $5.5 \mathrm{ft}$, which is considerably more than the tool joint's actual length of approximately 2 $\mathrm{ft}$. This discrepancy may be caused by the reduced thickness of insulation where the ID of the drillpipe body necks down near the tool joint. The total $k$ value for a complete drillstring must also be corrected for the fact that an average joint of drill pipe is approximately $32 \mathrm{ft}$ long, compared with the 25 -ft test vessel. Adjusting conductivity to reflect this additional length, the final composite conductivity value, based on pipe OD of 5 in and ID of 3.068 in, for a complete drillstring is $1.93 \mathrm{~B} / \mathrm{hr}-\mathrm{ft}-$ F.

\section{Modeling IDP Performance}

An important tool in IDP development has been the wellbore simulator ${ }^{1}$ GEOTEMP2. It is a finite-element code that calculates temperature in the flowing drilling fluid, during either stationary circulation or drilling ahead, by including convection inside and outside the drillpipe, conduction through the drillpipe, conduction through the casing, and convection between the fluid and casing. It also calculates formation temperature based on both vertical and radial conduction.

There are shortcomings in the code, related to its inability to model some aspects of the wellbore geometry and difficulty in specifying the initial temperature conditions for a given calculation, but it has proven extremely useful in evaluating the possibilities and options in designing a string of IDP. A sample calculation was shown in Fig. 1, but we can now use the composite-drillpipe conductivity to examine different configurations for a complete string of IDP. As an example, drilling fluid temperatures in a mixed string of IDP and CDP in a 10,000-ft well are shown in Fig. 6. These calculations show the effect of using $4,000 \mathrm{ft}$ of IDP at various points (top, middle, and bottom) in the string, compared to complete strings of $\mathrm{IDP}$ and CDP. Because this is a rather busy plot, a summary of these results is also shown in Table 1. In general, 
using only partial IDP (40\%) can still give significant benefit, compared with a complete string of CDP. If using a partialIDP string, then placing the IDP at the top gives maximum benefit; this is also consistent with placing the heaviest pipe at the top of the drill string.

The formation-temperature profile used in this calculation is one that is typical of geothermal wells, which often reach high temperature at relatively shallow depth. An alternative scenario, with the inflection point in the bi-linear formation temperature at $7,000 \mathrm{ft}$ instead of $3,000 \mathrm{ft}$, was also calculated. Results of that calculation are shown in Table 2, in the same format as in Table 1. In general, IDP has less effect on fluid temperatures in this case, which is reasonable, because the fluid is exposed to a lower average temperature during its circuit though the wellbore. Placement of IDP in a mixed string is also less critical, but strength considerations still argue for putting it at the top.

\section{IDP Field Test}

In May 1999, a field test on a 3,500-ft string of IDP was conducted in a geothermal well in the Imperial Valley of Southern California. The well had the undisturbed temperature profile shown in Fig. 7 (temperature profiles in the well before the CDP and IDP tests are also shown.)

Test Plan. The summary test plan was to first circulate through the CDP at two different flow rates, then pull out of the hole, wait for it to return to approximately the same beginning temperature profile as for the CDP, run in the hole with IDP, and circulate through the IDP at the same two flow rates as with the CDP. Another important objective of the test was to collect data for verification of GEOTEMP2. At the time of the test, the well had casing/liner set to approximately $4100 \mathrm{ft}$ but had not had the plug drilled out (i.e., there was no open hole, and no possibility of lost circulation.) Temperature was measured before and after each test with Sandia's resistance temperature tool and logging truck, and was measured during circulation with fiber-optic sensors both inside the drill pipe and strapped to the outside of the drill pipe. Other test parameters measured at the surface were flow rate, fluid temperature into the mud pumps, fluid temperature out of the flow line, and standpipe pressure while pumping. The optical fibers were encased and protected by capillary tubing, and the cap tubing inside the drill pipe was also used to suspend a Sandia pressure/temperature memory tool that stored bottomhole data for retrieval after each test.

Test Results. About 34 hours after the last drilling activity in the hole (cleaning out cement after liner was cemented and turning hole over from mud to water) a temperature log of the hole was done and the conventional (4-1/2-in, $16.6 \mathrm{lb} / \mathrm{ft}$ ) drill pipe was run in to $3600 \mathrm{ft}$ (the pipe did not go all the way to the bottom of the liner because two $4000-\mathrm{ft}$ pieces of optical fiber were not available.) Circulation was begun at $300 \mathrm{gpm}$ until one wellbore volume was displaced and then reduced to $150 \mathrm{gpm}$. After circulating at this rate for 2.5 hours, the flow rate was increased to $500 \mathrm{gpm}$ for 2.8 hours. Results of this test are shown in Fig. 8 (in each curve, the left-hand side is temperature in the drill pipe and the right-hand side is the annulus.) This figure also shows a comparison between actual temperatures measured by the fiber-optic sensors and predicted values calculated by GEOTEMP2; this agreement is generally good.

Following this series of circulations, the CDP was pulled out and logs were taken to verify temperature recovery. After the wellbore temperature came back to approximately the same profile as before the CDP test, the IDP was run into the hole. The same test procedure as for the CDP was followed, although circulation was not maintained for as long a time because temperature variation was less with the IDP.

When beginning circulation at $150 \mathrm{gpm}$, the slug of hot water at the bottom of the hole moved up the annulus without the cooling effect normally contributed by the cool downgoing fluid in the drill pipe. This meant that the much higher return temperatures caused some of the annular flow to flash to steam before temperatures stabilized. With the optical-fiber temperature profile measured in the annulus, however, it was possible to see the "bubble" of hot fluid moving up the annulus in real time, so that the driller could be aware of approaching boiling-point water. A time-lapse snapshot of annular temperatures is shown in Fig. 9. If a drilling situation dictates that excess return temperatures after resuming circulation are not acceptable, a few stands of conventional drill pipe could be placed at the top of the drill string to cool the returns as they near the surface; the CDP could then be quickly removed and replaced with IDP for drilling.

The critical aspect of performance, however, is comparison of temperature with CDP and IDP at the same flow rate, having started at roughly the same wellbore temperature profile and circulated for comparable times. This is shown in Fig. 10. After approximately one hour of circulation, bottom-hole temperature is $224^{\circ} \mathrm{F}$ with $\mathrm{CDP}$ compared to $112^{\circ} \mathrm{F}$ with IDP at 150 -gpm flow rate, which is similar to flow rates used with downhole motors. This bottomhole temperature is that which would be seen by downhole motors, steering tools, or measurement-while-drilling (MWD) instrumentation - even in this relatively cool well the temperature reduction is substantial. It is important to note that the bottom-hole cannot be significantly cooled by only lowering the mud inflow temperature; in the (calculated) case of CDP at $150 \mathrm{gpm}$ illustrated by Fig. 8, for example, lowering the inflow temperature by $20^{\circ} \mathrm{F}$ would only lower the bottom-hole temperature by $5.8^{\circ} \mathrm{F}$.

Hydraulics. Because the IDP has a smaller average ID than the CDP (3.068-in constant versus 3.826-in pipe with 2.812-in tool joints), there is greater pressure drop through the IDP at equivalent flow rates. Frictional pressure loss can be measured by combining standpipe and bottomhole pressures with static head of water at the appropriate temperature. At 500 gpm, pressure drops were $0.204 \mathrm{psi} / \mathrm{ft}$ in the IDP and 0.156 $\mathrm{psi} / \mathrm{ft}$ in the CDP. This difference is less than might be expected from consideration of the diameters, but the tool-joint diameter reduction apparently has a substantial effect on pressure drop in the 4-1/2-in drill pipe. 


\section{Conclusions}

There are three major questions to be answered about insulated drill pipe: how does it perform, can we predict the performance, and how should it be constructed?

Performance. The thermal performance has been good. It is close to calculated values and shows significant effect on drilling fluid temperature even in a relatively cool, shallow well. Structural performance has not yet been statistically confirmed through extensive field use, although several prototype joints used in drilling and workovers have shown no failure.

Prediction. The GEOTEMP2 code was effective in predicting IDP performance in the field test. It has also enabled extrapolation of IDP's effect in deeper wells. An improved wellbore simulator would be an asset to this development.

Fabrication. In considering the general concept of insulated drill pipe, there are three basic approaches: single-wall tube with insulation coating on the inside; single-wall tube with insulation on the outside; and double-wall tube with insulation in the annulus, or volume, between the tubes. Advantages and disadvantages of each method are summarized in Table 3 . Although there are clear advantages for a single-wall tube (most likely with insulation inside), pursuit of that goal has been deferred until the value of IDP has been demonstrated to and accepted by industry.

\section{Nomenclature}

$$
\begin{aligned}
k & =\text { thermal conductivity, } \mathrm{B} / \mathrm{hr}-\mathrm{ft}-\mathrm{F} \\
I D & =\text { inside diameter, inches } \\
O D & =\text { outside diameter, inches }
\end{aligned}
$$

\section{Acknowledgements}

We thank Elwood Champness, Drill-Cool Systems, for many informative discussions on insulated drill pipe and Gary Whitlow, Sandia National Laboratories, for assistance with data collection and recording in both laboratory and field tests. Sandia is a multi-program laboratory operated by Sandia Corporation, a Lockheed Martin Company, for the United States Department of Energy under Contract DE-AC04-94AL85000.

\section{References}

1. Mondy, L. A., Duda, L. E., "Advanced Wellbore Thermal Simulator GEOTEMP2 User Manual"; Sandia Report SAND840857, Sandia National Laboratories, Albuquerque, NM 871851033

\section{SI Metric Conversion Factors}

$$
\begin{array}{rlrl}
\mathrm{B} / \mathrm{hr}-\mathrm{ft}-\mathrm{F} \times 1.731 & \mathrm{E}+00 & =\mathrm{w} / \mathrm{m}-\mathrm{K} \\
\mathrm{ft} \times 3.048 & \mathrm{E}-01=\mathrm{m} \\
\mathrm{gpm} \times 6.309 & \mathrm{E}-05=\mathrm{m}^{3} / \mathrm{s} \\
\text { in } \times 2.54 & \mathrm{E}+00=\mathrm{cm} \\
\mathrm{psi} \times 6.895 & \mathrm{E}+00=\mathrm{kPa} \\
\mathrm{psi} / \mathrm{ft} \times 2.262 & \mathrm{E}+00=\mathrm{kPa} / \mathrm{m}
\end{array}
$$

\begin{tabular}{|c|c|c|c|}
\hline \multicolumn{4}{|c|}{ Table 3-Comparison of IDP construction } \\
\hline $\begin{array}{c}\text { Fabrication } \\
\text { method }\end{array}$ & Advantages & & Disadvantages \\
\hline $\begin{array}{l}\text { Single-wall, } \\
\text { insulation inside }\end{array}$ & $\begin{array}{l}\text { light weight; insula- } \\
\text { tion protected from } \\
\text { abrasion wear and } \\
\text { impact with casing o } \\
\text { wellbore; minimum } \\
\text { erosion from cut- } \\
\text { tings; could insulate } \\
\text { tool joints }\end{array}$ & & $\begin{array}{l}\text { iled insulation } \\
\text { uld plug bit or } \\
\text { ownhole motor, } \\
\text { fficult to install, } \\
\text { pair or replace } \\
\text { sulation; requires } \\
\text { ugh, strong insula- } \\
\text { on }\end{array}$ \\
\hline $\begin{array}{l}\text { Single-wall, } \\
\text { insulation outside }\end{array}$ & $\begin{array}{l}\text { light weight; in- } \\
\text { sulation easy to } \\
\text { apply; insulation } \\
\text { failure would not } \\
\text { have serious } \\
\text { effect on circula- } \\
\text { tion }\end{array}$ & $\begin{array}{l}\text { insule } \\
\text { erosic } \\
\text { proba } \\
\text { sulate } \\
\text { handl } \\
\text { body; } \\
\text { stron }\end{array}$ & $\begin{array}{l}\text { ation vulnerable to } \\
\text { on and impact; } \\
\text { ably could not in- } \\
\text { a tool joints or pipe- } \\
\text { ling areas of pipe } \\
\text { requires tough, } \\
\text { g insulation }\end{array}$ \\
\hline Double-wall & $\begin{array}{l}\text { reliable protection fo } \\
\text { insulation; no strengt } \\
\text { (except compressive } \\
\text { toughness requireme } \\
\text { on insulation; insulat } \\
\text { material developmen } \\
\text { not required }\end{array}$ & & $\begin{array}{l}\text { pipe is heavy; } \\
\text { fabrication and } \\
\text { material are } \\
\text { expensive; re- } \\
\text { duced inside } \\
\text { diameter affects } \\
\text { hydraulics }\end{array}$ \\
\hline
\end{tabular}

\begin{tabular}{|l|c|c|c|c|c|}
\hline \multicolumn{6}{|c|}{ Table 1 - Drilling fluid temperatures for different IDP } \\
configurations \\
\hline $\begin{array}{c}\text { All } \\
\text { CDP }\end{array}$ & $\begin{array}{c}\text { All } \\
\text { IDP }\end{array}$ & $\begin{array}{c}4 K^{\prime} \text { of } \\
\text { IDP @ } \\
\text { top }\end{array}$ & $\begin{array}{c}\text { 4K' of } \\
\text { IDP @ } \\
\text { bottom }\end{array}$ & $\begin{array}{c}\text { 4K' of } \\
\text { IDP in } \\
\text { middle }\end{array}$ \\
\hline $\begin{array}{l}\text { Returns } \\
\text { temp.,F }\end{array}$ & 163 & 196 & 182 & 170 & 175 \\
\hline $\begin{array}{l}\text { BH fluid } \\
\text { temp.,F }\end{array}$ & 401 & 165 & 232 & 278 & 250 \\
\hline $\begin{array}{l}\text { Max fluid } \\
\text { temp.,F }\end{array}$ & 406 & 215 & 244 & 306 & 261 \\
\hline
\end{tabular}

\begin{tabular}{|l|c|c|c|c|c|}
\hline \multicolumn{7}{|c|}{ Table 2 - Drilling fluid temperatures for different IDP } \\
configurations \\
\hline & $\begin{array}{c}\text { All } \\
\text { CDP }\end{array}$ & $\begin{array}{c}\text { All } \\
\text { IDP }\end{array}$ & $\begin{array}{c}4 K^{\prime} \text { of } \\
\text { IDP @ } \\
\text { top }\end{array}$ & $\begin{array}{c}4 K^{\prime} \text { of } \\
\text { IDP @ } \\
\text { bottom }\end{array}$ & $\begin{array}{c}4 K^{\prime} \text { of } \\
\text { IDP in } \\
\text { middle }\end{array}$ \\
\hline $\begin{array}{l}\text { Returns } \\
\text { temp., F }\end{array}$ & 136 & 154 & 146 & 140 & 142 \\
\hline $\begin{array}{l}\text { BH fluid } \\
\text { temp., F }\end{array}$ & 290 & 146 & 196 & 203 & 192 \\
\hline $\begin{array}{l}\text { Max fluid } \\
\text { temp., F }\end{array}$ & 297 & 177 & 205 & 225 & 206 \\
\hline
\end{tabular}




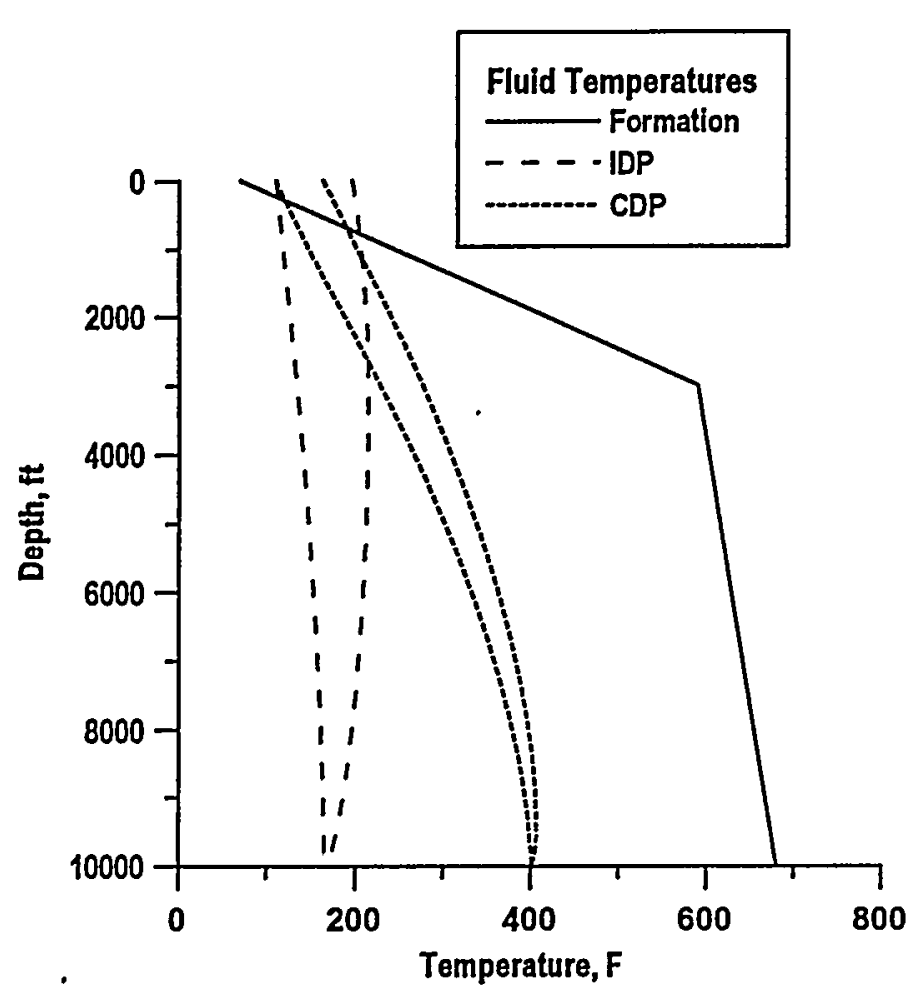

Fig. 1 - Comparison of temperatures in IDP and CDP

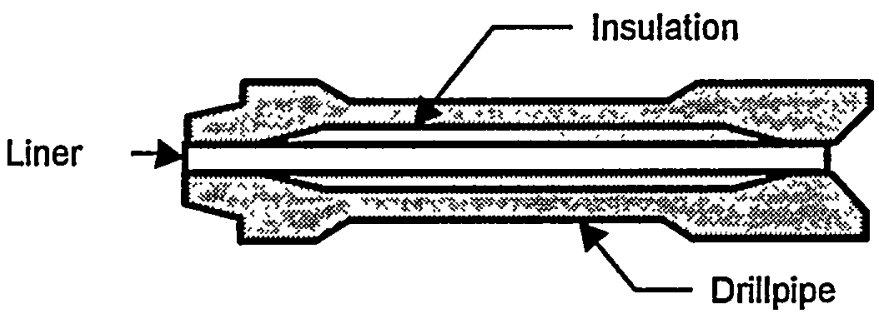

Fig. 2 - Schematic of Insulated Drillpipe

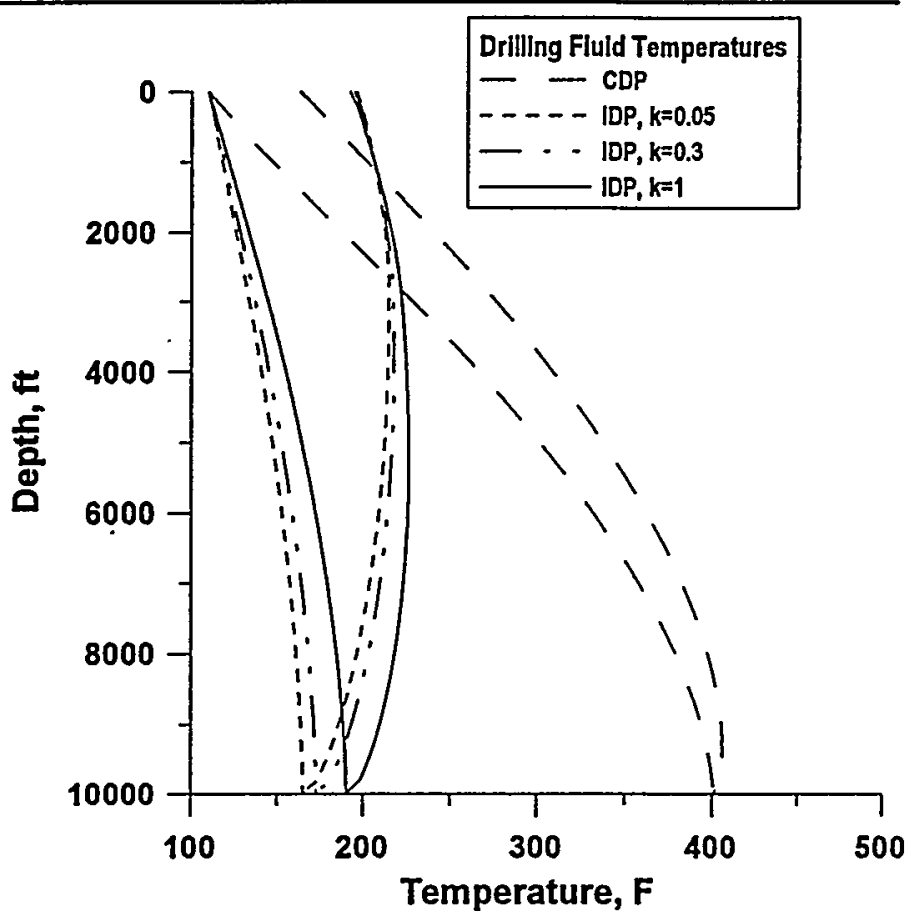

Fig. 3 - Comparison with different values of insulation in IDP

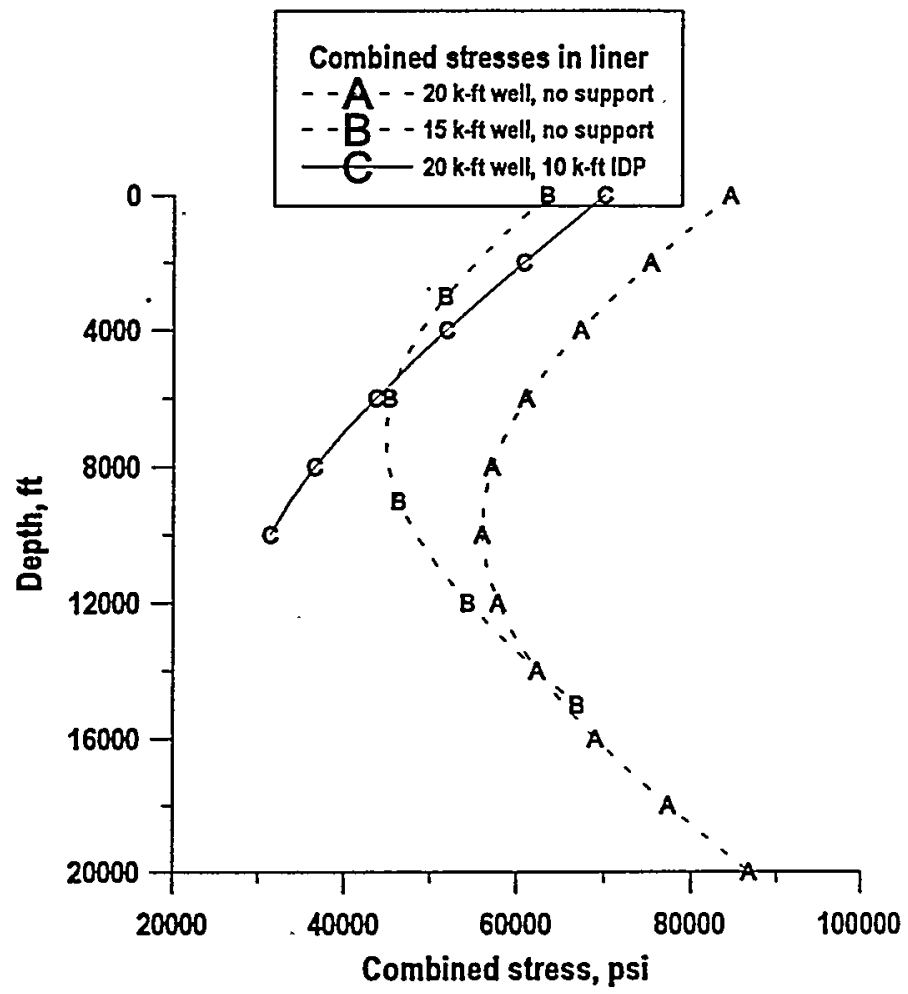

Fig. 4 - Combined stresses in liner tube under different loadings 


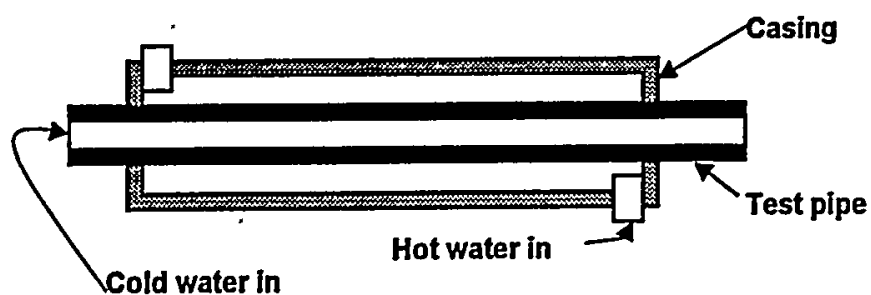

Fig. 5 - Apparatus for laboratory thermal test

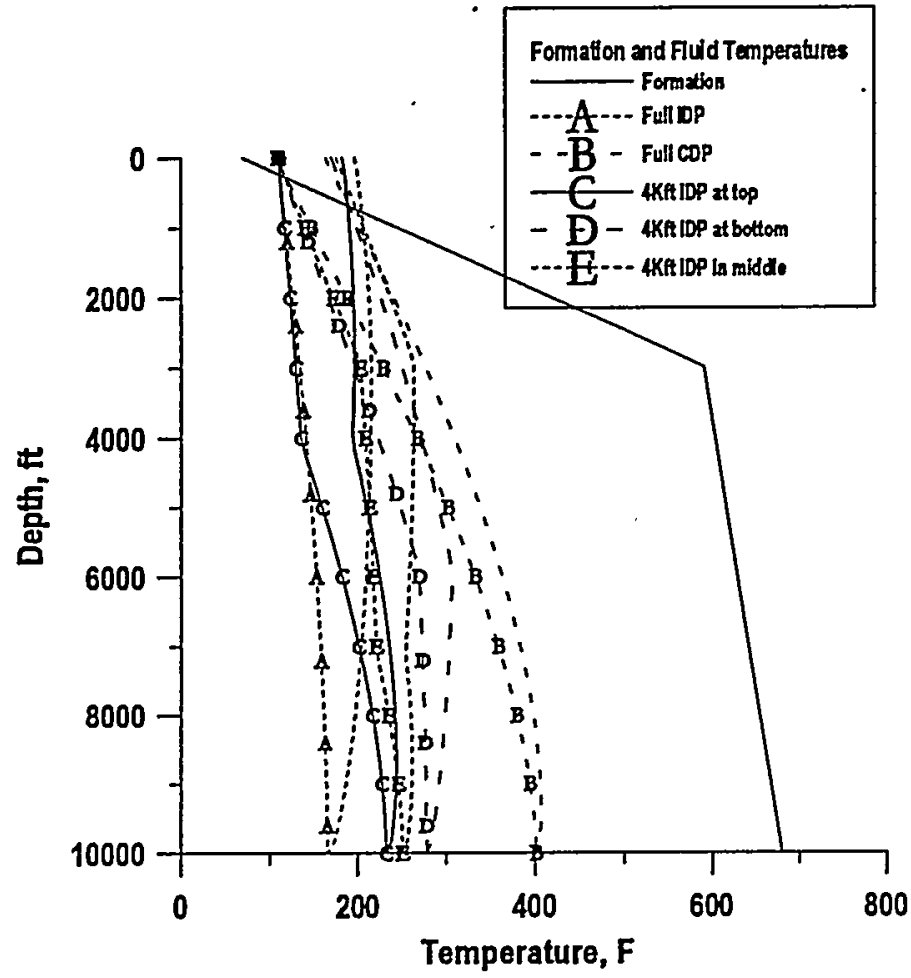

Fig. 6 - Temperatures with mixed (IDP and CDP) drill string

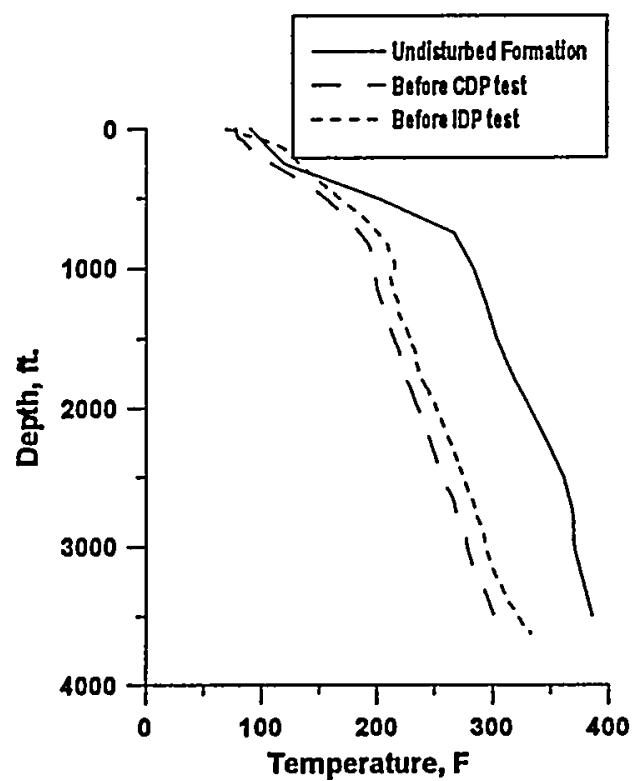

Fig. 7 - Beginning wellbore temperatures for field test

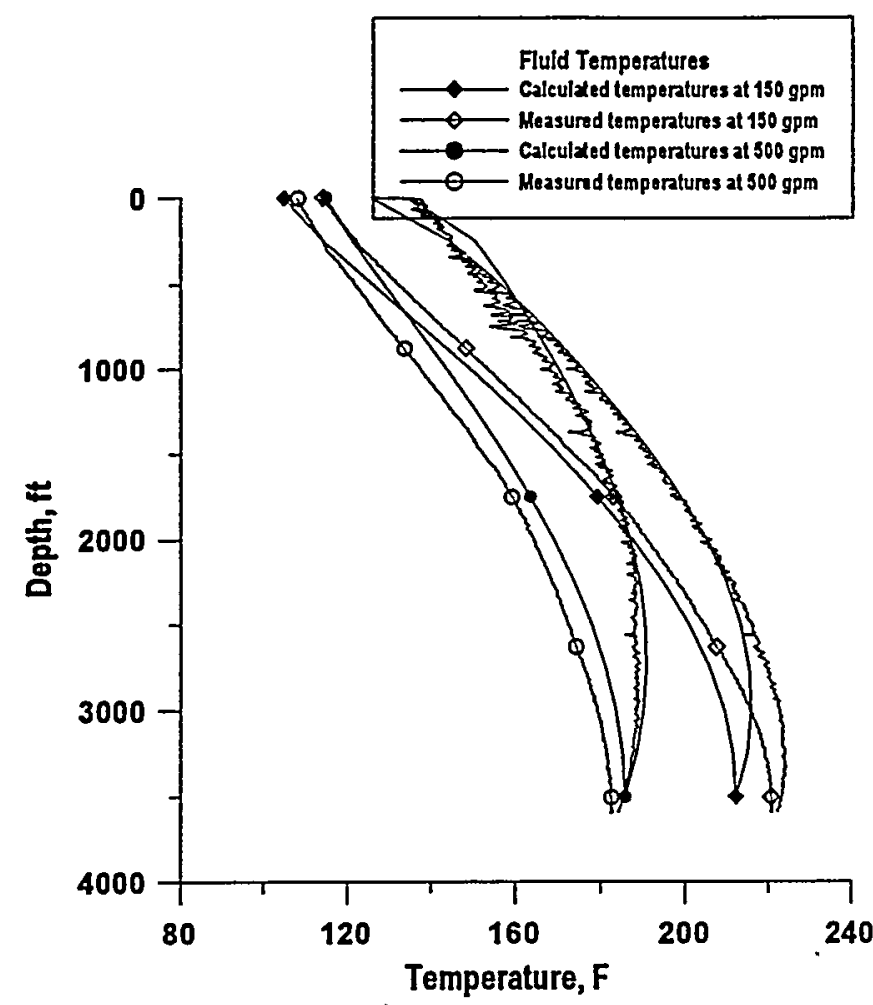

Fig. 8 - Measured and calculated temperatures in CDP

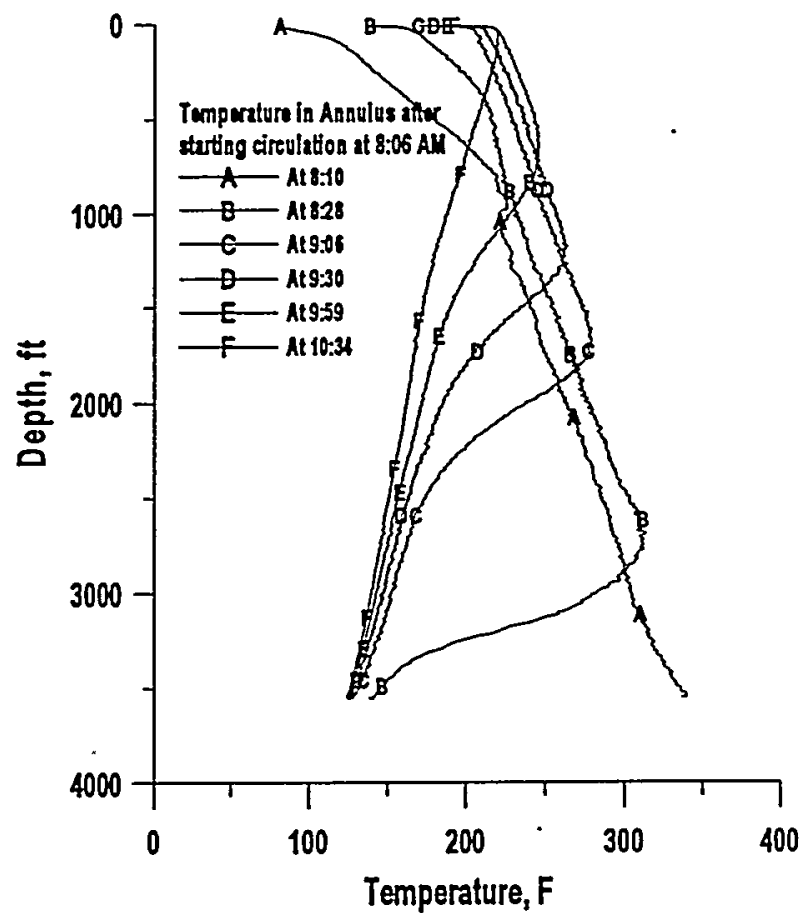

Fig. 9 - "Bubble" of hot fluid moving up the annulus after starting circulation with insulated drillpipe 


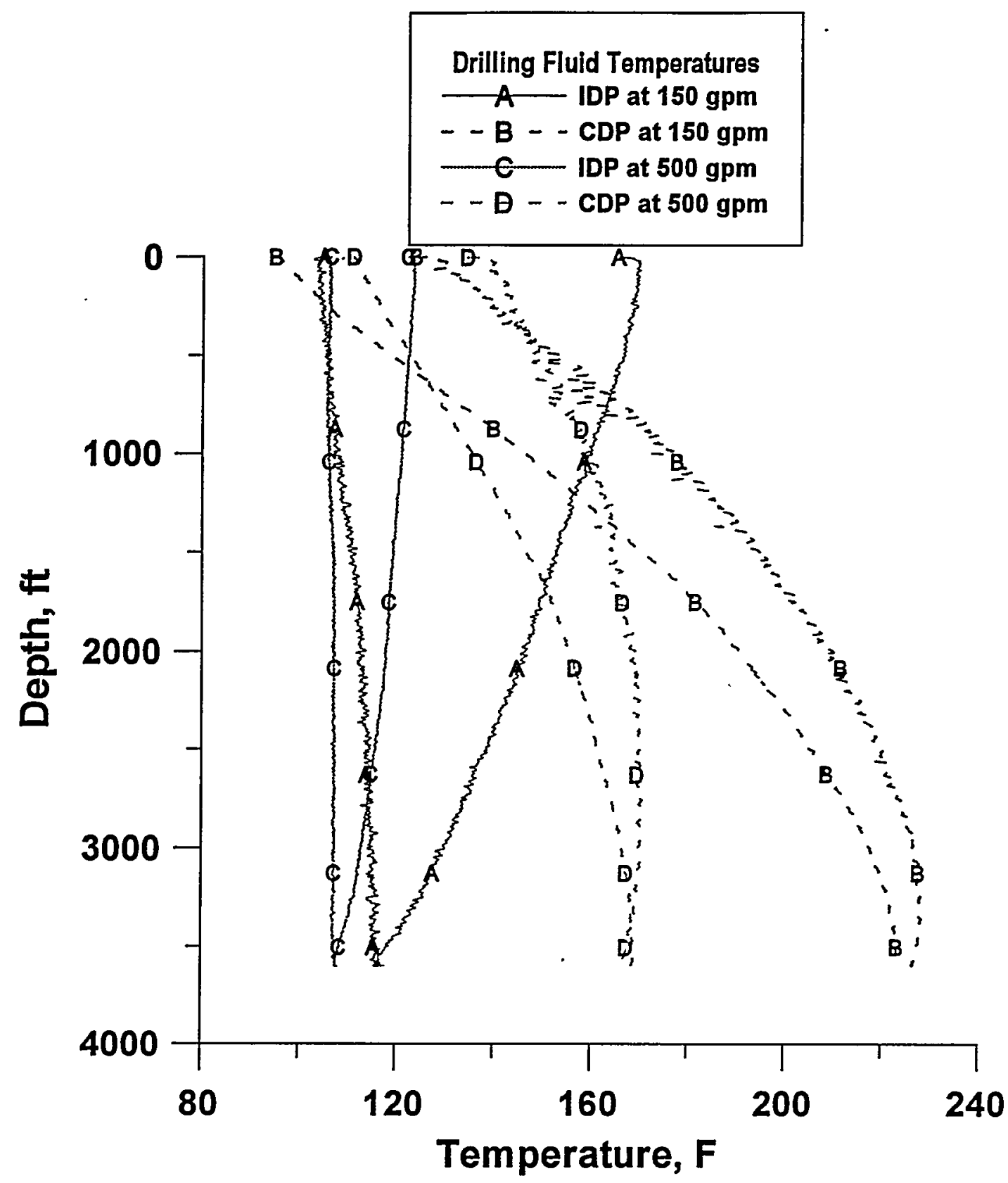

Fig. 10 - Comparison of fluid temperatures in IDP and CDP at two flow rates 